\title{
Influence of Ringer's lactated solution in continuous infusion and general anesthesia on hematocrit in dogs
}

\section{Influência da infusão contínua de solução de Ringer com lactato e da anestesia geral sobre o hematócrito em cães}

\author{
Rogério Luizari Guedes ${ }^{1 *}$; Verônica Souza Paiva Castro ${ }^{2}$; Heloísa Einloft Palma²; \\ Carolina Barbalho Hungria ${ }^{3}$; Carolina Posser Simeoni ${ }^{4}$; Marta Duarte ${ }^{5}$; \\ Ney Luis Pippi ${ }^{6}$; Peterson Triches Dornbusch ${ }^{7}$
}

\begin{abstract}
The measurement of serum parameters during general anesthesia procedures are subject to variations due to differences in protocol, splenic storage, and by the instituted fluid therapy. The aim of this study was to assess the hematocrit changes promoted by controlled fluid therapy and general anesthesia. Six mongrel female dogs underwent an anesthetic protocol with acepromazine $\left(0.03 \mathrm{mg} \mathrm{kg}^{-1}\right)$ and tramadol $\left(5 \mathrm{mg} \mathrm{kg}^{-1}\right)$ for premedication, induction with propofol $\left(3 \mathrm{mg} \mathrm{kg}^{-1}\right)$, and maintained with isoflurane and mechanical ventilation for 120 minutes. After induction, they were infused with $10 \mathrm{ml} \mathrm{kg} \mathrm{hr}{ }^{-1}$ of Ringer's lactate solution. Hematocrit measurements were performed from the start until 72 hours from anesthesia and evaluated statistically to check if there were significant changes over time. The fluid therapy, the acepromazine and propofol in the anesthetic protocol promotes a significant reduction of hematocrit up to four hours after general anesthesia.
\end{abstract}

Key words: Packed cell volume, crystalloids, acepromazine, propofol, bleeding

\section{Resumo}

\begin{abstract}
A mensuração de parâmetros séricos durante procedimentos dependentes de anestesia geral são passíveis de variações devido a diferenças do protocolo utilizado, armazenamento esplênico e também da fluidoterapia instituída. O objetivo deste trabalho foi avaliar o hematócrito buscando evidenciar as alterações flutuantes promovidas por fluidoterapia controlada e anestesia geral em cães submetidos a ovariohisterectomia laparoscópica. Seis cadelas sem raça definida foram submetidas a um protocolo anestésico com acepromazina $\left(0,03 \mathrm{mg} \mathrm{kg}^{-1}\right)$ e tramadol $\left(5,0 \mathrm{mg} \mathrm{kg}^{-1}\right)$ como medicação pré-anestésica, indução com propofol $\left(3,0 \mathrm{mg} \mathrm{kg}^{-1}\right)$ e mantidas com isoflurano e ventilação mecânica durante 120 minutos. Após a indução, receberam a infusão de $10,0 \mathrm{ml} \mathrm{kg} \mathrm{hr}^{-1}$ de solução Ringer com lactato. Foram realizadas aferições de hematócrito do início (ou antes?) até 72 horas após a anestesia, sendo avaliadas
\end{abstract}

\footnotetext{
${ }^{1}$ Discente, Programa de Pós-graduação em Ciências Veterinárias, Universidade Federal do Paraná, UFPR, Curitiba, PR. Brasil. E-mail: rogerioguedes@veterinario.med.br

2 Discentes, Programa de Pós-graduação em Medicina Veterinária, Universidade Federal de Santa Maria, UFSM, Santa Maria, RS. Brasil. E-mail: castrove@gmail.com; heinloft@hotmail.com

3 Pesquisador, Clinivet Hospital Veterinário, Curitiba, PR. Brasil. E-mail: carolinabhungria@hotmail.com

${ }^{4}$ Pesquisador, Secretaria Estadual de Agricultura e Agropecuária, Santa Maria, RS. Brasil. E-mail: carol.posser@hotmail.com

5 Pesquisador, Labimed Análises Clínicas, Santa Maria, RS. Brasil. E-mail: duartmm@hotmail.com

${ }^{6}$ Prof., Dept ${ }^{\circ}$ de Clínica de Pequenos Animais, Universidade Federal de Santa Maria, UFSM, Santa Maria, RS. Brasil. E-mail: nlpippi@gmail.com

${ }^{7}$ Prof., Dept ${ }^{\circ}$ de Medicina Veterinária, Universidade Federal do Paraná, UFPR, Curitiba, PR. Brasil. E-mail: petriches@gmail.com

* Author for correspondence
} 
estatisticamente para verificar se houve alterações relevantes durante os tempos. A fluidoterapia e o uso de acepromazina e propofol no protocolo anestésico para esta técnica cirúrgica promoveram uma redução de hematócrito significativa até quatro horas após a anestesia geral.

Palavras-chave: Volume globular, cristalóides, acepromazina, propofol, hemorragia

A common question in a surgical routine is to determine whether the reduction of hemoglobin and hematocrit (ht) are due to hemodilution or hemorrhage (GRATHWOHL; BURNS, 1996). The ht associated with plasma volume, allows evaluation of total blood volume by percentages. However, their goal defines blood cell mass that can also be measured by cell staining with chromium (JAIN, 1993). Furthermore, hematocrit is one of the parameters in evaluating acute blood loss, and the hydration and hemodilution of the patient must always be considered during the red blood cells evaluation, since fluid therapy causes a reduction of total plasma proteins (tpp) and ht (JAIN, 1993).

Evaluation of plasma parameters for procedures that need general anesthesia and surgery are subjected to variations due to differences such as the anesthetic protocol, splenic storage (LOPES et al., 2006; WILSON et al., 2004) and also by the fluid type and its route of administration (LOBO et al., 2001; 2010). Crystalloids are used to maintain plasma volume, but pass freely through the capillaries and only a small part of them remains in the blood when infused (PERSSON; GRÄNDE, 2006). The major changes in serum parameters occur when bolus administration is carried out (GRATHWOHL; BURNS, 1996).

Currently, there are no studies correlating hematocrit changes with anesthetic protocols and fluid therapy in dogs, at least quantitatively, related to hemodilution. Therefore, this study aimed to estimate hematocrit values that may indicate transitory changes promoted by a controlled fluid therapy protocol associated with general anesthesia, developed for laparoscopic ovariohysterectomy in bitches.
This study has approval from the Ethics Committee for Animal Experimentation of the Federal University of Santa Maria (Rio Grande do Sul - Brazil), under protocol number 008/2011. Six canines, healthy adult females $(12.6 \pm 4.7 \mathrm{~kg})$ underwent a preoperative clinical and hematologic evaluation including complete blood count, platelet count and biochemical tests for serum creatinine, albumin, and alanine aminotransferase. After 12 hours fasting, the animals received premedication (MPA), intramuscularly (IM), with acepromazine $\left(0.03 \mathrm{mg} \mathrm{kg}^{-1}\right)$ and tramadol hydrochloride $(5 \mathrm{mg}$ $\left.\mathrm{kg}^{-1}\right)$. After 15 minutes, the animals were induced to general anesthesia with propofol $\left(3 \mathrm{mg} \mathrm{kg}^{-1}\right)$, maintained at a $1.8 \% \mathrm{~V}$ expired isoflurane that allowed a mean arterial pressure between 65 and 75 $\mathrm{mmHg}$ and pressure-cycled ventilation $(15 \mathrm{mmHg})$ for maintenance of the expired $\mathrm{CO}_{2}$ fraction between 35 and $45 \mathrm{mmHg}$. Epidural anesthesia was made with $2 \%$ lidocaine hydrochloride with epinephrine $\left(1 \mathrm{ml} 4 \mathrm{~kg}^{-1}\right)$ and morphine $\left(0.1 \mathrm{mg} \mathrm{kg}^{-1}\right)$. After induction, the patient received continuous infusion of Ringer's lactate solution through cephalic vein venoclysis, controlled by infusion pump $\left(10 \mathrm{ml} \mathrm{kg}^{-1}\right.$ $\mathrm{hr}$ ). With the onset of general anesthesia, all patients were probed for bladder emptying and controlled urine output. Complementary to the protocol designed for laparoscopic procedures, cephalothin (30 $\mathrm{mg} \mathrm{kg}^{-1}$ ) was administered as an antimicrobial prophylactic, thirty minutes before the surgical procedure. The dogs underwent anesthesia for 120 minutes, kept in the right lateral position, and this decubitus was switched to the left after 60 minutes. Also, complementary to the ovariohysterectomy protocol, patients received in their post-anesthetic subcutaneous administrations of meloxicam (0.2 $\mathrm{mg} \mathrm{kg}{ }^{-1}$, SID) and tramadol hydrochloride (3 $\mathrm{mg}$ $\mathrm{kg}^{-1} \mathrm{TID}$ ), over three days. 
The determination of microhematocrit and total plasma protein are according to the techniques described by Feldman et al. (2000). With a total of nine measurements per patient, samples were collected at the time immediately prior to the application of MPA, immediately after the start of anesthetic maintenance and fluid, 30, 60, 90 minutes and after the procedure (120 min). New measurements occurred after four, 24 and 72 hours after anesthesia.

The values registered for parametric statistical analysis, using Pearson's correlation coefficient followed by quadratic regression test and $\mathrm{F}$ test $(p<0.05)$. There was a highly significant correlation $(p<0.0001)$ between the changes in $\mathrm{ht}$ and ppt, showing that both have undergone similar changes during the times evaluated. The quadratic regression test was first used for the individual assessment of each patient, finding no significant changes in the parameters for the trans-anesthetic periods (30, 60, 90 and $120 \mathrm{~min})$, for all animals. The same occurred between the measurements before MPA and after anesthetic induction and fluid therapy, and there were no significant differences between the post-anesthetic periods (four, 24, 72 hours). Thus, the values without significant differences were grouped as means for further examination with the quadratic regression test, which was statistically significant $(p<0.05)$ in some comparisons. Samples collected during the anesthetic procedure (30, 60, 90 and $120 \mathrm{~min})$ obtained the mean values of $34.63 \pm 5.9 \%$ for hematocrit and $7.24 \pm 0.54 \mathrm{~g} \mathrm{dl}^{-1}$ for total plasma protein. Comparing those results with the MPA and after induction of anesthesia and fluid (ht $45 \pm$ $7.72 \%$; tpp $8.73 \pm 0.64 \mathrm{~g} \mathrm{dl}^{-1}$ ), we have a decrease. The samples after the procedures showed increase and maintenance of values in four, 24 and 72 hours $\left(43.61 \pm 6.72 \% \mathrm{ht}\right.$; tpp $\left.8.16 \pm 0.57 \mathrm{~g} \mathrm{dl}^{-1}\right)$, similar to those obtained in the preoperative evaluation. When comparing the above data between pre- and post-anesthetic periods, there were no statistical differences.
In none of the patients did the urinary output exceed the recommended as normal rates for healthy

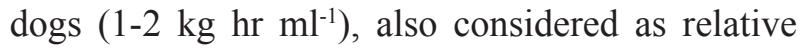
oliguria on fluid therapy patients, which confirms that there were no water and electrolyte loss by renal excretion (LANGSTON, 2008).

In humans, more than $68 \%$ of crystalloid infusions remain in the interstitial fluid (LOBO et al., 2010), and its fast implementation causes significant decrease in ht at up to eight hours (GRATHWOHL; BURNS, 1996), a reduction of up to $7.5 \%$ with the use of $0.9 \%$ saline solution after an hour of application (LOBO et al., 2001). In dogs, Chohan et al. (2011) considered that the ht decrease through hemodilution was promoted by Ringer's lactate infusion, but did not consider the blood loss or the anesthetic protocol inherent to the procedure. Empirically, the ht reduction by the protocol used can be approximately $10 \%$, but the decline began prior to fluid therapy $(36.2 \pm 1.64 \%)$, indicating that it may have contributed to this reduction in the values obtained 30 minutes after the beginning of the procedure.

The packed cell volume decrease is considered the most pharmacological response characteristic of the IM application of acepromazine, promoting relaxation of the splenic capsule and erythrocyte sequestration (LEISE et al., 2007). Thus, it can be assumed that this drug has great importance in the decrease prior to the fluid therapy, even when applied in small doses. The use of barbiturates cause splenomegaly but the association of propofol and acepromazine can make smaller hemoconcentrations than other protocols in dogs (WILSON et al., 2004). Moreover, the same author states that the administration of propofol generates ht decreases between $4-7 \%$ of the value obtained after the MPA, results that corroborate those found in this study (37\%). The isoflurane does not promote hematological changes during trans- and post-operative times (DOGAN et al., 1999). Although there were no hemogasometric evaluations, mechanical ventilation 
occurred without complications, and as Batista et al. (2010) describe, it performed this function without deleterious effects on the cardiovascular system.

As for the analgesic protocol, Valverde (2008) states that the epidural technique with morphine and lidocaine may cause hypotension and respiratory depression, however, there is no direct assessment of changes in hematological parameters. Studies confirm that the use of meloxicam does not change the serum parameters in the trans-surgical period (FRESNO et al., 2005) as well as longterm administration (ALENCAR et al., 2003). Tramadol hydrochloride apparently does not cause hematological changes, and at least during this study no papers were found describing alterations because of its use, but the opposite statement is also not present.

The protocol promoted significant changes in hematocrit and total plasma protein up to four hours after anesthesia; fluid therapy and the administration of acepromazine and propofol are primarily responsible for the described changes. However, it would be necessary for supplementary isolated reviews to define the contribution of each one. The decrease set around $10 \%$ can help differentiate acute blood loss and hemoconcentration or hemodilution during surgical procedures and the immediate postoperative period.

\section{References}

ALENCAR, M. M. A.; PINTO, M. T.; OLIVEIRA, D. M.; PESSOA, A. W. P.; CÂNDIDO, I. A.; VIRGÍNIO, C. G.; COELHO, H. S. M.; ROCHA, M. F. G. Margem de segurança do meloxicam em cães: efeitos deletérios nas células sanguíneas e em trato gastrintestinal. Ciência Rural, Santa Maria, v. 33, n. 3, p. 525-532, 2003.

BATISTA, P. A. C. S.; NUNES, N.; BORGES, P. A.; MORO, J. V.; LOPES, P. C. F.; BARBOSA, V. F.; BELMONTE, E. A. Efeitos da ventilação com pressão de suporte sobre as variáveis cardiovasculares e respiratórias em cães anestesiados com propofol. Medvep - Revista Científica de Medicina Veterinária - Pequenos Animais e Animais de Estimação, Curitiba, v. 8, n. 26, p. 515-518, 2010.
CHOHAN, A. S.; GREENE, S. A.; GRUBB, T. L.; KEEGAN, R. D.; WILLS, T. B.; MARTINEZ, S. A. Effects of 6\% hetastarch $(600 / 0.75)$ or lactated Ringer's solution on hemostatic variables and clinical bleeding in healthy dogs anesthetized for orthopedic surgery. Veterinary Anaesthesia and Analgesia, Oxford, v. 38, n. 2, p. 94-105, 2011. Available at: <http://onlinelibrary. wiley.com/doi/10.1111/j.1467-2995.2010.00589.x/pdf>. Accessed at: 15 maio 2011.

DOGAN, I. V.; OVALI, E.; ETI, Z.; YAYCI, A.; GOGUS, F. Y. The in vitro effects of isoflurane, sevoflurane, and propofol on platelet aggregation. Anesthesia \& Analgesia, v. 88, n. 2, p. $432-436,1999$.

FELDMAN, B. V.; ZINKL, J. G.; JAIN, N. C. Schalm's veterinary hematology. Philadelphia: Lippincott Williams \& Wilkins, 2000. 1344 p.

FRESNO, L.; MOLL, J.; PEÑALBA, B.; ESPADA, Y.; ANDALUZ, A.; PRANDI, D.; GOPEGUI, R. R.; GARCÍA, F. Effects of preoperative administration of meloxicam on whole blood platelet aggregation, buccal mucosal bleeding time, and haematological indices in dogs undergoing elective ovariohysterectomy. The Veterinary Journal, London, v. 170, n. 1, p. 138-140, 2005.

GRATHWOHL, K. W.; BURNS, B. J. Does hemodilution exist? Effects of saline infusion on hematologic parameters in euvolemic subjects. Southern Medical Journal, v. 89, n. 1, p. 51-57, 1996.

JAIN, N. C. Blood loss or hemorrhagic anemias. In: . Essentials of veterinary hematology. Philadelphia: Lea \& Febiger, 1993. p. 169-176.

LANGSTON, C. Managing fluid and electrolite disorders in renal failure. Veterinary Clinics of North America: Small Animal Practice, Philadelphia, v. 38, n. 3, p. 677697, 2008.

LEISE, B. S.; FUGLER, L. A.; STOKES, A. M.; EADES, S. C.; MOORE, R. M. Effects of intramuscular administration of acepromazine on palmar digital blood flow, palmar digital arterial pressure, transverse facial arterial pressure, and packed cell volume in clinically healthy, conscious horses. Veterinary Surgery, v. 36, n. 8, p. 717-723, 2007.

LOBO, D. N.; STANGA, Z.; ALOYSIUS, M. M.; WICKS, C.; NUNES, Q. M.; INGRAM, K. L.; RISCH, L.; ALLISON, S. P. Effect of volume loading with 1 litre venous infusions of $0,9 \%$ saline, $4 \%$ succinylated gelatin (Gelofusine), hydroxyethyl starch (Voluven), on blood volume and endocrine responses: a randomized, threeway crossover study in healthy volunteers. Critical Care Medicine, v. 38, n. 2, p. 464-470, 2010. 
LOBO, D. N.; STANGA, Z.; SIMPSON, J. A. D.; ANDERSON, J. A.; ROWLANDS, B. J.; ALLISON, S. P. Dilution and redistribution effects of rapid 1-litre infusions of $0,9 \%(\mathrm{w} / \mathrm{v})$ saline and $5 \%(\mathrm{w} / \mathrm{v})$ dextrose on haematological parameters and serum biochemistry in normal subjects: a double-blind crossover study. Clinical Science, v. 101, p. 173-179, 2001. Available at: <http:// www.clinsci.org/cs/101/0173/1010173.pdf>. Accessed at: 12 nov. 2010.

LOPES, S. T. A.; MACIEL, R. M.; FRANCISCATO, C.; EMANUELLI, M. P.; RIVERA, R. S.; MAZZANTI, A.; TEIXEIRA, L. V. Reticulócitos e hematócrito de cães pré e pós esplenectomia parcial. Ciência Rural, Santa Maria, v. 36, n. 3, p. 1000-1003, 2006.
PERSSON, J.; GRÄNDE, P. Plasma volume expansion and transcapillary fluid exchange in skeletal muscle of albumin, dextran, gelatin, hydroxyethyl starch, and saline after trauma in the cat. Critical Care Medicine, v. 34, n. 9, p. 2456-2462, 2006.

VALVERDE, A. Epidural analgesia and anesthesia in dogs and cats. Veterinary Clinics of North America: Small Animal Practice, Philadelphia, v. 38, n. 6, p. 12051230, 2008.

WILSON, D. V.; EVANS, A. T.; CARPENTER, R. E.; MULLINEAUX, D. R. The effect of four anesthetic protocols on splenic size in dogs. Veterinary Anaesthesia and Analgesia, Oxford, v. 31, n. 2, p. 102-108, 2004. Available at: <http://onlinelibrary.wiley.com/ doi/10.1111/j.1467-2987.2004.00152.x/pdf>. Accessed at: 15 maio 2011. 
